\title{
Asthma in Preschool Children: A Review of the Diagnostic Challenges
}

\author{
Andrew J. Cave, MB ChB, MClSc, FCFP, FRCGP, and Lana L. Atkinson, MLIS
}

Family physicians face many challenges when diagnosing asthma in preschool children. These diagnostic challenges are compounded by variations in the natural history of early stage asthma, which are not fully understood, since early childhood wheezing and asthma are heterogeneous disorders with many phenotypic and variable expressions. Since no standard definition for the type, severity, or frequency of symptoms exist for this age group, clear evidence-based recommendations are lacking. Without adequate guidance, family physicians are left to make diagnostic and treatment decisions, which can lead to undertreatment of asthmatics and overtreatment of transient wheezers. New guidelines that specifically address the challenges of diagnosing asthma in this particular age group (Global Initiative for Asthma, British Thoracic Society/Scottish Intercollegiate Guidelines Network) have recently been published, and researchers are actively seeking new methods and techniques through epidemiological studies to assist primary care clinicians in the diagnostic process. This review has wide application in primary care. By recognizing the diagnostic challenges and understanding the related best practices, family physicians will be better placed to treat, manage, and control asthma symptoms, resulting in lower morbidity rates and reduced health system costs, as well as enhancing the overall quality of life and well-being of the children affected. (J Am Board Fam Med 2014;27:538-548.)

Keywords: Asthma, Child, Preschool, Diagnosis, Primary Health Care

Asthma is the most common chronic condition among children worldwide ${ }^{1}$ and is characterized by episodes of cough, wheezing, and shortness of breath; reversible airflow limitation; and bronchial hyperresponsiveness. ${ }^{2}$ Preschool-aged children $(\leq 5$ years old) suffering from this heterogeneous disorder, particularly those within underserved populations $^{3}$ and minorities, ${ }^{4}$ frequently experience daytime fatigue and reduced activity levels, potentially hindering their developmental progress and diminishing social interaction.

To date, evidence suggests that early intervention is important. ${ }^{5,6}$ However, diagnosing pre-

This article was externally peer reviewed.

Submitted 18 October 2013; revised 17 March 2014; accepted 24 March 2014.

From the Department of Family Medicine, University of Alberta, Edmonton, Alberta, Canada.

Funding: none.

Conflict of interest: none declared.

Corresponding author: Andrew J. Cave, MB ChB, MClSc, FCFP, FRCGP, Department of Family Medicine, University of Alberta, 901 College Plaza, Edmonton T6G 2C8, Alberta, Canada (E-mail: andrew.cave@ualberta.ca). school children is difficult and often results in undertreatment of asthmatics and overtreatment of transient wheezers. ${ }^{7,8}$ Therefore, a correct diagnosis is the first step toward effective treatment and management of asthma ${ }^{9}$ and thereby lowering potential harm due to misdiagnosis. ${ }^{10}$

This evidence-based review article presents many challenges associated with diagnosing asthma in preschool children. It also offers solutions to these challenges and identifies areas of research that are contributing to an improved understanding of the diagnostic process. It is hoped that this information will help facilitate the accurate and timely diagnosis of asthma in preschool children in a variety of health care settings and geographic locations.

\section{Data Sources and Selection Criteria}

We based this review on the Global Initiative for Asthma guidelines published in 2009 and 2012 11,12 ; the British Thoracic Society/Scottish Intercollegiate Guidelines Network Guidelines on the Management of Asthma, published and updated in $2012^{13}$; 
the National Heart, Lung, and Blood Institute Expert Panel Report 3, Guidelines for the Diagnosis and Management of Asthma, published in 2007. ${ }^{5} \mathrm{We}$ also included key publications by the World Health Organization. ${ }^{1-14}$ MEDLINE, CINAHL, and the Cochrane Library were searched for publications between 2007 and 2013, using the search terms astbma, cough, wheezing, breathlessness, diagnosis, management, barriers, primary care, preschool, and childhood. We also searched cited references using the Web of Science, as well as our personal research article archive, to investigate and review relevant publications. All published guidelines agree on the current need for (or lack of) a gold standard for diagnosing asthma in preschool children and the associated challenges and solutions therein.

\section{Why is Diagnosing Preschool Children with Asthma So Difficult?}

Young children are particularly difficult to diagnose with asthma for a variety of reasons. ${ }^{15}$ First, the diagnosis is a clinical one, since there is no standard definition of the type, severity, or frequency of symptoms. The absence of a standard definition means that it is not possible to make clear evidence-based recommendations on how to diagnose asthma. ${ }^{8,11,13-16}$

Another challenge is that airflow limitation or airway inflammation, the main pathologic hallmarks of asthma, are difficult to assess in this age group. ${ }^{17}$ Lung function measurements that are key to diagnosing asthma in older children and adults are not reliable in young children. ${ }^{18}$ Consequently, diagnoses are largely based on reported symptoms, in contrast to diseases connected to organs or those identified with blood tests or scans (eg, cancer) or that can be related to causal factors (eg, certain bacteria, such as tuberculosis). ${ }^{19}$ These diagnostic challenges are compounded by variations in the natural history of the early stage of asthma, which are not fully understood because early childhood wheezing and asthma are heterogeneous disorders with many phenotypic and variable expressions. ${ }^{20}$

Many symptoms that support an asthma diagnosis in young children are not necessarily "asthma specific." For example, cough and wheezing may be seen in healthy children or are characteristic of other pediatric diseases. ${ }^{21}$ Therefore, differentiating the symptoms of asthma from those of other diseases in otherwise healthy children relates not only to the presence and absence of certain symptoms but also to their frequency, severity, and pattern (seasonal and diurnal). ${ }^{22}$ Trigger factors and the age of the child must also be considered. ${ }^{18-22}$ All such alternatives must be examined before a diagnosis of asthma is made.

Although it is known that asthma is a multifactorial disease that may have different expressions depending on family and medical history, lifestyle, and environmental exposures, ${ }^{23}$ uncertainties about the fundamental causes of asthma remain. ${ }^{12}$ Understanding the causes and risk factors that each child may be exposed to is important when making a diagnosis, particularly because morbidity and mortality differ between racial and ethnic groups, suggesting possible genetic predispositions. ${ }^{23}$ Also, inconsistencies in the delivery of asthma care exist. Although the underlying causes for such differences are complex, they relate in part to the interrelationships between poverty, cultural differences, access to and the quality of care, the difficulties in reducing exposure to allergens, and problems that patients and families may have in adhering to treatment regimens. ${ }^{23}$

Collectively, an implication of these challenges is that early childhood asthma is frequently misdiagnosed as chronic bronchitis, wheezy bronchitis, reactive airway disease, recurrent pneumonia, gastroesophageal reflux, or recurrent upper respiratory tract infections. Therefore, many infants and young children do not receive adequate or appropriate therapy. ${ }^{5}$ However, evidence on which to base any recommendations for young children is limited. There are many reasons for this, including the scarcity of objective end points and the difficulties associated with ethical issues in researching very young children. ${ }^{24}$

\section{What Is the Approach to Addressing These Challenges When Assessing for Asthma? Take a Careful History}

Establishing an accurate family history can be useful in identifying patterns of inheritance, as well as recognizing long-term patterns of episodic respiratory signs and symptoms that could not be attributed to any alternative conditions. ${ }^{13,23}$ This symptoms-only descriptive approach, which recommends including various phenotypic definitions of wheezing, is an important component during history taking. ${ }^{7,11,17,25-27}$ Identifying such patterns helps guide diagnostic, therapeutic, and preventive approaches. ${ }^{28}$ 
Epidemiologic studies have identified a number of factors about a child's history that should be obtained, including, but not limited to:

- timing and pattern of wheezing (either acute or chronic);

- associated factors, such as the relationship of these episodes to viral illness and feeding and history of comorbid conditions;

- response to previous treatments;

- family history of atopic disease;

- personal history of atopic disease;

- social and environmental factors that seem to contribute to morbidity;

- maternal diet during pregnancy and/or lactation; and

- psychosocial factors. ${ }^{17,20}$

Clear, understandable, and culturally sensitive discussion between a clinician and their patient is a prerequisite for effective communication of symptoms during history taking. ${ }^{29}$ However, young children provide a special challenge in communicating symptoms, primarily because it is the parent who must often interpret their child's descriptions of the symptoms or the physical signs they observe and describe these symptoms to the clinician.

\section{Patient-Centered Care: Engaging Preschool Children in the Diagnostic Process}

Traditionally, clinicians generally exclude children younger than the age of 10 from discussions about their illness. ${ }^{30,31}$ However, the following recommendations may facilitate a better patient-centered care approach with children ${ }^{31}$ :

1. Engage with children's expertise about their own lives, including their personal and social experiences of their care, as well as how these experiences are affected by their relative lack of power in some settings.

2. Explore children's understanding and preferences in terms of their physical sensations and day-to-day experiences.

3. Be willing to find resources to engage even the youngest children.

4. Avoid age-based assumptions about children's contributions to their care.

These recommendations may present a range of challenges in health care settings, not least because they represent a move toward engaging with young children's experiences from their earliest ages. ${ }^{31}$ However, diabetic children as young as 4 years old were reported to actively monitor their diet, interpret physical symptoms, perform their own blood tests and insulin injections at the correct time, as well as explain their illness to others. ${ }^{31,32}$ Researchers who engaged with younger children also used a range of methods to help the children explain their illness. These included meeting children in comfortable, nonthreatening environments and providing them with materials to demonstrate, draw, or role-play their experiences. ${ }^{31-35}$

However, challenges of implementing these types of patient-centered care in clinical practice include the extra time and resources needed to seek out young children's experiences. ${ }^{31}$ It may be difficult to justify these additional resources during times of funding pressure. Nevertheless, the extent to which a child's lack of engagement in health care settings affects their lives should not be overlooked. ${ }^{31}$ Considering these complex barriers has implications for practice, research, and policy changes that should be made. ${ }^{23}$

\section{What About "Wheeze"?}

Failure to treat a child's asthma appropriately may be due to a child's inaccurate description of their symptoms; ineffective communication with the clinician; inappropriate action by the clinician, the parent, or the child; or misinterpretation of the symptoms (such as wheezing) by the parent. ${ }^{29}$

Wheezing is a very common symptom in young children, as are upper respiratory tract infections. Therefore, all that wheezes is not necessarily asthma. Since development of asthma during childhood is highly variable and the common symptoms are so nonspecific, it follows that diagnosis and treatment are largely based on verbal interactions, with parents presenting the child's history of illness secondhand. ${ }^{19,36}$

Wheezing is one of a number of respiratory noises that occur in children and is defined as a continuous high-pitched sound with a musical quality emitting from the chest during expiration. ${ }^{7}$ It is important to distinguish wheezing from other respiratory noises such as stridor or rattly breathing. ${ }^{13,37,38}$ However, parents differ widely in their understanding of wheeze, with definitions ranging from a whistling, squeaking, or gasping sound to a different rate or style of breathing. Others think it 
is the same as cough. Consequently, parents often use "wheezing" as a nonspecific name for any abnormal respiratory noise, ${ }^{37}$ potentially resulting in the child being labeled and treated as a wheezer when he or she is not. ${ }^{7,39}$

The unreliability of parental recognition of wheeze has been recognized in studies using a videobased questionnaire ${ }^{40}$ or objective recording of lung sounds. ${ }^{41}$ The significance of these sounds is very different, and time must be spent when taking a child's history to determine exactly what the parent means. ${ }^{21,42}$ Therefore, the clinician's challenge is to ask good questions based on the typical pattern of asthma is preschool-aged children and in the context of the parents' vocabulary and understanding. ${ }^{43}$

\section{Other Factors to Consider During History Taking}

Because of divorce, fractured family relationships, or loss, it may be emotionally difficult for some to recount their family history. ${ }^{28}$ Alternatively, some children may have multiple family members caring for them, without a single adult assuming primary responsibility, so that establishing a complete family history becomes difficult. ${ }^{28}$

Maternal distress has been associated with the development of childhood asthma, so understanding the child's birth history is an important part of the diagnostic process. ${ }^{44}$ Dreger and colleagues ${ }^{45}$ investigated the association between children's cortisol concentrations and the combined predictors of exposure to maternal distress and childhood asthma. Among children exposed to recurrent maternal stress, Dreger et al found that an increase in cortisol concentrations occurs in response to an acute stressor when there is no diagnosis of asthma; however, children with asthma tend to exhibit lower cortisol concentrations. Similar results were reported by Wright et al. ${ }^{46}$ After evaluating an innercity population, Wright and colleagues reported an association between prenatal stress and altered innate and adaptive immune responses to cord blood mononuclear cells. They suggested that stress-induced perinatal immunomodulation might affect the expression of allergic disease in children.

Brasholt et $\mathrm{al}^{47}$ studied the association between physical activity in preschool children and objectively assessed intermediary asthma phenotypes. They concluded that physical activity in preschool children was reduced with increasing bronchial responsiveness. This reduction was subclinical and not recognized by parents or doctors despite daily diary cards and close postnatal clinical follow-up. They recommended that increased recognition of even very mild, subclinical asthma symptoms is important. ${ }^{44,47}$

Proposed strategies for improving asthma care include the use of standardized screening questionnaires to assess symptoms using the modified Asthma Predictive Index (mAPI) and to predict likelihood using the Asthma Control Questionnaire and the Asthma Control Test. The Asthma Predictive Index (API) was derived from data from the Tucson cohort and developed to help clinicians identify those children who will continue wheezing into older childhood. ${ }^{20}$ The most impressive aspect of the API is its ability to determine the likelihood that young children with wheezing will develop asthma by school age. ${ }^{15,44}$

The API includes risk factors such as frequent wheezing, parental history of asthma, and signs of personal atopy. ${ }^{5,48}$ The API was recently modified, replacing the clinical diagnosis of allergic rhinitis with evidence for allergic sensitization ${ }^{20,49}$ (see Table 1). The mAPI has been described and endorsed by the Expert Panel Report 3, and although it is not prospectively validated, it might be a useful tool in identifying children who are more likely to have

\section{Table 1. Modified Asthma Predictive Index (API)} versus Original API*

1. A history of $\geq 4$ wheezing episodes with $\geq 1$ physician's diagnosis.

2 . In addition, the child must meet $\geq 1$ of the following major criteria or $\geq 2$ of the following minor criteria:

\begin{tabular}{lc}
\hline \multicolumn{2}{c}{ Major Criteria } \\
\hline Modified API & Original API \\
\hline $\begin{array}{l}\text { Parental history of asthma } \\
\text { Doctor-diagnosed atopic } \\
\text { dermatitis }\end{array}$ & $\begin{array}{l}\text { Parental history of asthma } \\
\text { Doctor-diagnosed atopic } \\
\text { dermatitis }\end{array}$ \\
$\begin{array}{c}\text { Allergic sensitization to } \\
\geq \mathbf{1} \text { aeroallergen }\end{array}$ & \\
\hline
\end{tabular}

\begin{tabular}{lc}
\hline \multicolumn{2}{c}{ Minor Criteria } \\
\hline $\begin{array}{l}\text { Modified API } \\
\text { Allergic sensitization to } \\
\text { milk, egg, or peanut } \\
\begin{array}{l}\text { Wheezing unrelated to } \\
\text { colds }\end{array}\end{array}$ & $\begin{array}{c}\text { Ooctor-diagnosed } \\
\text { allergic rhinitis } \\
\text { Blood eosinophils } \geq 4 \%\end{array}$ \\
\hline
\end{tabular}

${ }^{*}$ Differences between indices are shown in boldface. Reprinted with permission from Bacharier and Gilbert. ${ }^{20}$ 
persistent wheezing and who might respond to inhaled corticosteroids. The sensitivity and specificity of the mAPI have yet to be determined. ${ }^{20}$

Other strategies for improving care include more frequent routine visits for children with persistent symptoms; more widely disseminating realistic goals for symptom control ${ }^{29}$; and maintaining active dialogue so that information is readily available and shared. ${ }^{28}$ However, collecting accurate, detailed, and, when necessary, updated family information is time consuming. ${ }^{28}$ Lack of time often relates to parents who are working full-time or clinicians lacking the support or motivation to obtain the information. ${ }^{28}$

Despite constraints in applying family history information to primary pediatric practice, tools are available to assist clinicians with the efficient collection and application of this information. ${ }^{28}$ These tools can be tailored according to the needs of each family, as well as the strengths and challenges of the practice setting and patient population. ${ }^{28}$

\section{Perform a Thorough Clinical Examination}

Asthma in young children can often be diagnosed by identifying symptom patterns by carefully assessing family history and performing a physical examination. ${ }^{50}$ The presence of atopy or allergic sensitization provides additional diagnostic criteria, since these symptoms increase the likelihood that a wheezing child has asthma, ${ }^{17,51}$ but a clinical examination is mandatory.

Even if a child is not experiencing any respiratory symptoms of distress at the time of the clinical examination, the physical examination is a useful component of the diagnostic process. A physical assessment can determine whether the child has an atopic disorder, as well as identify any physical signs (such as digital clubbing or a severe chest deformity) suggesting a more serious underlying diagnosis or a systemic disorder. ${ }^{52}$ Such examinations should be comprehensive and focus on both the upper and lower respiratory tracts, chest, and skin. $^{20,53}$

Physicians also need to be aware of the complex, age-dependent relationships that may lead to differential diagnoses of wheezing during childhood, particularly because this possibility increases the younger the child is. ${ }^{8}$ It is also important that physicians broaden their differential diagnosis to help decrease the likelihood of diagnostic errors. ${ }^{10}$ Table 2 presents an age-related review of the dif-
Table 2. Age-Related Differential Diagnosis for Wheezing

\begin{tabular}{|c|c|c|c|}
\hline \multirow[b]{2}{*}{ Condition } & \multicolumn{3}{|c|}{ Relative Frequency of Occurrence } \\
\hline & Infancy & Childhood & Adolescence \\
\hline Asthma & + & +++ & +++ \\
\hline Airway malacia & ++ & + & - \\
\hline Cystic fibrosis & +++ & + & \pm \\
\hline Foreign body & ++ & +++ & \pm \\
\hline Airway infection & +++ & ++ & + \\
\hline $\begin{array}{l}\text { Bronchopulmonary } \\
\text { dysplasia }\end{array}$ & +++ & + & - \\
\hline Primary ciliary dyskinesia & + & ++ & + \\
\hline Bronchiectasis & + & + & + \\
\hline $\begin{array}{l}\text { Congenital anomalies } \\
\text { (vascular ring) }\end{array}$ & +++ & + & - \\
\hline Vocal cord dysfunction & - & \pm & ++ \\
\hline Tumors & \pm & \pm & \pm \\
\hline $\begin{array}{l}\text { Aspiration syndromes } \\
\text { (including } \\
\text { gastroesophogeal } \\
\text { reflux) }\end{array}$ & + & \pm & \pm \\
\hline Pulmonary edema & + & + & + \\
\hline
\end{tabular}

- , Unlikely to present in this age group; + , likely to present in this age group.

Reprinted from Bacharier and Gilbert ${ }^{20}$ and Bacharier ${ }^{54}$; originally modified from Bierman and Pearlman. ${ }^{55}$

ferential diagnoses during infancy, childhood, and adolescence. $^{20,54,55}$

\section{What Is the Role of Lung Function Testing?}

Although spirometry and tests such as airway responsiveness and markers of airway inflammation are used for diagnosing older children and adults, their use on young children is difficult, and several require complex equipment, making them unsuitable for routine use. ${ }^{12,20,56}$ In the past decade, however, a small number of studies were conducted to assess the feasibility of spirometry in young children. ${ }^{48,57}$ These concluded that spirometry is feasible in children 3 to 6 years of age and may be useful for clinical practice and research purposes.

Lung function testing, bronchial challenge, and other physiologic tests have a minor role in the diagnosing asthma in children $<5$ years old because of the child's inability to perform reproducible expiratory maneuvers. ${ }^{17}$ Nevertheless, children 4 to 5 years old can be taught to use a peak expiratory flow meter, although supervision is required to ensure reliability. ${ }^{12}$ For this age-group, however, spirometry would be more feasible if strict reproducibility criteria were not applied. Results showed that be- 
Table 3. Tips for Diagnosing Asthma in Preschool Children for Family Physicians

Taking a careful patient and parental history is critical in the diagnostic process.

When assessing for asthma, a child's physical symptoms and history fall into one of the following categories: (1) not asthma; (2) possibly asthma; or (3) definitely asthma.

You don't have to make a diagnosis in one visit.

Ask about symptoms and use of preventive therapies at every visit. Relevant information can be obtained at every visit.

Younger children with viral-induced asthma respond well to leukotriene receptor antagonist therapy.

Follow-up and control assessment is as important as blood pressure measurement.

Diagnosing the type of asthma affects management (intermittent/viral or persistent/seasonal).

Of children with persistent asthma, 50\% have symptoms (i.e., are uncontrolled).

Of children who have respiratory syncytial virus, $50 \%<2$ years old will develop asthma.

The mainstay of prevention for children is low-dose inhaled steroids, but the vast majority of children never need a combination of inhaled glucocorticosteroids and long-acting bronchodilators.

tween $50 \%$ and $92 \%$ of 3 - to 6-year-olds produced a minimum of 2 acceptable curves, with a margin of error of $<10 \%$. $^{48,58-60}$

There has been increasing interest in applying and developing lung function testing in young children. The American Thoracic Society (ATS) and European Respiratory Society (ERS) formed a Joint Expert Panel to review the feasibility and reliability of spirometry in young children. The Joint Panel published an official statement that acknowledged that the current repeatability criteria for adult spirometry are not appropriate for preschool children. ${ }^{57}$ They proposed modifying the criteria so that young children are required to produce at least 2 acceptable curves that are within $10 \%$ of each other. They also gave researchers and clinicians the option of accepting only one curve if there is no doubt that it was technically satisfactory. ${ }^{57}$

In addition, forced expiratory volume (FEV) can be measured over half a second $\left(\mathrm{FEV}_{0.5}\right)$ as opposed to 1 whole second $\left(\mathrm{FEV}_{1}\right)$. The Panel explained that $\mathrm{FEV}_{0.5}$ is physiologically more appropriate for young children because they have large airways relative to absolute lung volume compared to adults, and forced expiration is therefore completed over a shorter period. ${ }^{57}$

The ATS/ERS statement encourages clinicians and researchers to make accommodations for young children to obtain good results and improve reproducibility. The report suggests making the laboratory child friendly and offering adequate time to complete the tests using incentive spirometry software that is interactive and animated. The ATS/ERS outline areas for research and improvement that would make spirometry more reliable in young children and a better tool for clinical practice. $^{48,57}$

\section{Closely Monitor and Evaluate Treatment Trials}

A trial of treatment (at least 8 to 12 weeks) with short-acting bronchodilators and inhaled glucocorticosteroids for persistent asthma may indicate the presence of asthma. ${ }^{12}$ These interventions should be evaluated in terms of how they control daytime and nocturnal symptoms, as well as the effectiveness of increasing the dose of inhaled or systemic glucocorticosteroids on reducing the frequency of exacerbations. Identifiable clinical improvement during treatment and deterioration after discontinuing it supports a diagnosis of asthma. ${ }^{12,17}$ However, many children exhibit the seasonal/intermittent asthma phenotype, so repeated therapeutic trials may be needed to be confident of the diagnosis. ${ }^{17}$ For additional diagnostic tips for nonspecialists, see Table 3. However, when diagnosis is in doubt, especially in the early wheezer, specialist referral should be considered (see Table 4 for information on when to refer to a specialist).

\section{Table 4. Situations in Which Specialist Referral Should be Considered When Asthma Diagnosis is Inconclusive}

When a child $<1$ year old has recurrent episodes of wheezing, at which time congenital causes of wheezing, rather than asthma, are more common.

When diagnosis is in doubt, especially in the early wheezer.

If asthma is difficult to control, consider other diagnoses or referral.

When a child with suspected asthma does not respond to inhaled corticosteroids after 8 weeks of good adherence.

Refer children $\geq 5$ years old with persistent type asthma for diagnostic spirometry at a local facility if this is not reliably available in the practice. Spirometry for younger children ( $>3$ years old) can be modified and often is useful in aiding diagnosis.

Refer to a allergy specialist for skin testing if a specific allergen is not obvious from the history and clinical allergy assessment.

Refer to an asthma educator for assistance in control assessment (as well as instruction in action plans and inhaler technique). 


\section{Conclusions}

Correct diagnosis is the basis for asthma care and is the first step in reducing the symptoms, effects on lifestyle, and risk of adverse effects that are associated with the disease. ${ }^{5}$ Diagnosis and intervention during the early stages of asthma is important, since the severity of lung function impairment is related to the duration of the disease. ${ }^{6}$ It is also important for health care professionals to recognize that despite some similarities, important differences exist between asthma in adults and children. ${ }^{13}$ These differences relate to natural history and comorbidities, and so it becomes important for the clinician to modify their approach according to the age of the patient. Therefore, care and attention must be paid to the special considerations of children, especially preschool-aged children.

However, perhaps the most important thing for primary practitioners to recognize is that they will encounter many children for whom a definitive diagnosis simply cannot be made, and the issues around under- and overtreating may never be resolved. Instead, the focus should be to establish a relationship built on trust whereby the lines of good communication are kept open during the treatment, management, and follow-up of the disease. This perhaps creates the best diagnostic outcome and therapy for the child.

\section{Future Directions}

Although clinical approaches, predictive tests (eg, mAPI), and trials with bronchodilators or glucocorticosteroids are still helpful, new avenues to early diagnosis and treatment may include adopting epidemiologic research, which focuses on more accurate phenotypic approaches. ${ }^{8}$ Furthermore, the development of new diagnostic tools (eg, nitric oxide testing) in recent years, such as the identification of volatile organic compounds in exhaled breath, have helped distinguish between asthma and transient wheezing. ${ }^{8,61}$ For example, the Asthma Detection and Monitoring Study is developing a noninvasive instrument to monitor inflammation in young children ( 2 to 3 years old) using exhaled inflammatory markers and early lung function measurements. It will potentially avoid both overtreatment of children with transient wheeze and undertreatment of children with asthma. ${ }^{62}$

Induced sputum testing also has potential for being a useful tool; however, it is technically de- manding as well as time consuming, which is why it currently is not recommended in clinical practice. ${ }^{8,63,13}$ See Table 5 for other ongoing and emerging research efforts.

In the primary care setting, effective asthma care for children should extend beyond a traditional biomedical model based on current guidelines to a more holistic and comprehensive (rather than episodic) approach that incorporates an ongoing assessment of the family's environment and socioeconomic status and their willingness to engage in and adapt to diagnostic and treatment regimens. ${ }^{23}$ Fur-

Table 5. Ongoing and Emerging Research in the Diagnosis of Asthma in Preschool Children

\begin{tabular}{|c|c|}
\hline Topic & Description \\
\hline $\begin{array}{l}\text { Vitamin D } \\
\text { supplementation }\end{array}$ & $\begin{array}{l}\text { Some convincing data of a possible } \\
\text { link between maternal vitamin D } \\
\text { intake during pregnancy and } \\
\text { subsequent risk of wheeze have } \\
\text { emerged. }{ }^{24,64,65} \text { Vitamin D } \\
\text { supplementation during } \\
\text { pregnancy may therefore be a } \\
\text { very real option for achieving a } \\
\text { primary preventive strategy for } \\
\text { early onset wheeze. Before this } \\
\text { is formally undertaken, however, } \\
\text { studies investigating the } \\
\text { mechanism of action of vitamin } \\
\text { D are needed, as any potential } \\
\text { harmful effects of } \\
\text { supplementation during } \\
\text { pregnancy should be known. }\end{array}$ \\
\hline RCPCH care pathway & $\begin{array}{l}\text { Asthma and rhinitis are conditions } \\
\text { that commonly coexist. The } \\
\text { Royal College of Paediatrics and } \\
\text { Child Health Science and } \\
\text { Research Department developed } \\
\text { a national asthma/rhinitis care } \\
\text { pathway for children with } \\
\text { allergies, commissioned by the } \\
\text { Department of Health. These } \\
\text { conditions have remarkably } \\
\text { similar immunopathology; } \\
\text { therefore an integrated long- } \\
\text { term management approach has } \\
\text { been shown to improve } \\
\text { symptom control and quality of } \\
\text { life. }{ }^{54}\end{array}$ \\
\hline $\begin{array}{l}\text { Link between gut } \\
\text { microbiota, method } \\
\text { of birth/delivery, } \\
\text { and asthma }\end{array}$ & $\begin{array}{l}\text { The disruption of the gut } \\
\text { microbiota during caesarean } \\
\text { delivery and formula feeding has } \\
\text { been linked to an increasing } \\
\text { number of diseases, including } \\
\text { asthma. These long-term health } \\
\text { consequences may be partially } \\
\text { attributable to the disruption of } \\
\text { gut microbiota. }{ }^{66} \text { By } \\
\text { understanding birth history, } \\
\text { clinicians may be better able to } \\
\text { understand factors that } \\
\text { contribute to asthma during } \\
\text { childhood. }\end{array}$ \\
\hline
\end{tabular}


Table 6. Educational Resources for Physicians and Parents Caring for Preschool Children with Asthma

\begin{tabular}{|c|c|c|}
\hline Resource & Description & URL \\
\hline \multicolumn{3}{|l|}{ Family physicians } \\
\hline $\begin{array}{l}\text { Pocket Guide for Asthma } \\
\text { Management and Prevention in } \\
\text { Children } 5 \text { Years and Younger: } \\
\text { A Pocket Guide for Physicians } \\
\text { and Nurses }\end{array}$ & $\begin{array}{l}\text { Global Initiative for Asthma (GINA) 2009, } \\
\text { based on the full Global Strategy for } \\
\text { Astbma Management and Prevention in } \\
\text { Children } 5 \text { Years and Younger }\end{array}$ & http://www.ginasthma.org \\
\hline $\begin{array}{l}\text { The National Coalition for } \\
\text { Health Professional Education } \\
\text { in Genetics }\end{array}$ & $\begin{array}{l}\text { A summary of available family history } \\
\text { tools and educational aids }\end{array}$ & $\begin{array}{l}\text { http://www.nchpeg.org/index.php?option= } \\
\text { com_content } \& \text { view }=\text { article\&id }= \\
61 \& \text { Itemid }=74\end{array}$ \\
\hline Canadian Lung Association & $\begin{array}{l}\text { A comprehensive site with resources to aid } \\
\text { in pediatric diagnosis }\end{array}$ & http://www.lung.ca/home-accueil_e.php \\
\hline \multicolumn{3}{|l|}{$\begin{array}{l}\text { Resources for patients and } \\
\text { caregivers }\end{array}$} \\
\hline Bubblioboo (GINA) & $\begin{array}{l}\text { An interactive asthma information resource } \\
\text { and educational game for young } \\
\text { children }\end{array}$ & http://www.ginasthma.org/Patients \\
\hline $\begin{array}{l}\text { iCAN Control Asthma at the } \\
\text { University of Calgary, Canada }\end{array}$ & $\begin{array}{l}\text { Links to an Asthma Diagnosis Checklist } \\
\text { that patients and their families can fill } \\
\text { out before their next doctor's } \\
\text { appointment }\end{array}$ & http://www.ucalgary.ca/icancontrolasthma \\
\hline $\begin{array}{l}\text { Lungtropolis provided by the } \\
\text { American Lung Association } \\
\text { and ORCAS }\end{array}$ & $\begin{array}{l}\text { A new and interactive learning site for } \\
\text { children and the parents of children } \\
\text { with asthma }\end{array}$ & http://www.lungtropolis.com/ \\
\hline $\begin{array}{l}\text { asthmakids.ca by the Asthma } \\
\text { Society of Canada }\end{array}$ & $\begin{array}{l}\text { Provides an interactive, child-friendly site } \\
\text { with a comprehensive compilation of } \\
\text { education resources and games }\end{array}$ & http://www.asthmakids.ca/global/aboutUs.php \\
\hline Asthma UK & $\begin{array}{l}\text { A nonprofit charitable organization that } \\
\text { provides links to a variety of free online } \\
\text { resources for parents with young } \\
\text { children who have suspected asthma or } \\
\text { have been recently diagnosed }\end{array}$ & http://www.asthma.org.uk/advice-is-it-asthma \\
\hline
\end{tabular}

thermore, diagnostic approaches require demographic adaptations that consider variations in health care resources within different clinical practice settings. ${ }^{11}$

Despite these promising approaches and innovative tools, some level of uncertainty in diagnosing asthma in preschool children in general practice settings likely exists. ${ }^{8,22}$ However, these uncertainties can be reduced using effective interventions that recognize the challenges of diagnosis and extend beyond routine health care by providing the necessary investment in social and community resources. These interventions involve behavioral and lifestyle changes, increased educational resources (Table 6), provision of adequate housing, and environmental reforms. ${ }^{23,67}$

Through our comprehensive review of numerous national and international practice guidelines and evaluation of the most up-to-date evidence, we conclude that demographic variations based on socioeconomic conditions, genetic diversity, cultural beliefs, and differences in health care access and delivery influence the diagnostic approach of clinicians. ${ }^{18}$ By understanding these best practices and recognizing diagnostic challenges, health care providers will be better placed to treat, manage, and control asthma symptoms, resulting in lower rates of morbidity and reduced health system costs, as well as enhancing the overall quality of life and well-being of the children affected.

The authors thank Christine Graf for her contribution during the initial search and retrieval of articles used in this review.

\section{References}

1. World Health Organization (WHO). Asthma. Fact sheet no. 307. Available from: http://www.who.int/ mediacentre/factsheets/fs307/en/index.html. Updated November 2013. Accessed May 16, 2014.

2. Spahn JD, Covar R. Clinical assessment of asthma progression in children and adults. Clin Rev Allergy Immunol 2008;121:548-57.

3. Tartasky D. Asthma in the inner city: a growing public health problem. Holist Nurs Pract 1999;14: $37-46$. 
4. Bonilla S, Kehl S, Kwong KYC, Morphew T, Kachru R, Jones CA. School absenteeism in children with asthma in a Los Angeles inner city school. J Pediatr 2005;147:802-6.

5. National Heart, Lung, and Blood Institute. Expert Panel Report 3 (EPR3): guidelines for the diagnosis and management of asthma. Full report, 2007. Available from: http://www.nhlbi.nih.gov/guidelines/asthma/ asthgdln.pdf. Accessed May 16, 2014.

6. Hafkamp-de Groen E, Mohangoo A, de Jongste J, et al. Early detection and counselling intervention of asthma symptoms in preschool children: study design of a cluster randomised controlled trial. BMC Public Health 2010;10:555.

7. Brand PLP, Baraldi E, Bisgaard H, et al. Definition, assessment and treatment of wheezing disorders in preschool children: an evidence-based approach. Eur Respir J 2008;32:1096-110.

8. Baena-Cagnani CE, Badellino HA. Diagnosis of allergy and asthma in childhood. Curr Allergy Asthma Rep 2011;11:71-7.

9. Busse WW. Asthma diagnosis and treatment: filling in the information gaps. J Allergy Clin Immunol 2011;128:740-50.

10. Ely JW, Kaldjian LC, D’Alessandro DM. Diagnostic errors in primary care: Lessons learned. J Am Board Fam Med 2012;25:87-97.

11. Global Initiative for Asthma (GINA). Global strategy for the diagnosis and management of asthma in children 5 years and younger. Available from: http://www.ginasthma.org/Global-Strategy-forthe-Diagnosis-and-Management-of-Asthma-inChildren-5-Years-and-Younger. Updated May 2009. Accessed May 16, 2014.

12. Global Initiative for Asthma (GINA). 2012 Update: global strategy for asthma management and prevention. Available from: http://www.ginasthma.org/ documents/5/documents_variants/37. Accessed May 16, 2014.

13. British Thoracic Society (BTS), Scottish Intercollegiate Guidelines Network (SIGN). British guideline on the management of asthma: a national clinical guideline. Available from: https://www.brit-thoracic.org.uk/ document-library/clinical-information/asthma/ btssign-guideline-on-the-management-of-asthma/. Accessed May 16, 2014.

14. World Health Organization (WHO). Global surveillance, prevention and control of chronic respiratory diseases: a comprehensive approach, 2007. Available from: http://www.who.int/gard/publications/GARD_ Manual/en/. Accessed May 16, 2014.

15. Castro-Rodriguez JA. The Asthma Predictive Index: early diagnosis of asthma. Curr Opin Allergy Clin Immunol 2011;11:157-61.

16. Roberts G. Predicting the long-term outcome of preschool wheeze: are we there yet? J Allergy Clin Immunol 2009;124:911-12.
17. Pedersen SE, Hurd SS, Lemanske RF Jr, et al. Global strategy for the diagnosis and management of asthma in children 5 years and younger. Pediatr Pulmonol 2011;46:1-17.

18. Global Initiative for Asthma (GINA). Pocket guide for asthma management and prevention in children 5 years and younger. Available from: http://www. ginasthma.org/Global-Strategy-forthe-Diagnosisand-Management-of-Asthma-in-Children-5-Years-andYounger. Updated May 2009. Accessed May 16, 2014.

19. Finnvold JE. In their own words: early childhood asthma and parents' experiences of the diagnostic process. Scand J Caring Sci 2010;24:299-306.

20. Bacharier LB, Gilbert TW. Diagnosis and management of early asthma in preschool-aged children. J Allergy Clin Immunol 2012;130:287-96.

21. Bush A. Diagnosis of asthma in children under five. Prim Care Respir J 2007;16:7-15.

22. Pedersen S. Preschool asthma-not so easy to diagnose. Prim Care Respir J 2007;16:4-6.

23. Swartz MK, Banasiak NC, Meadows-Oliver M. Barriers to effective pediatric asthma care. J Pediatr Health Care 2005;19:71-9.

24. Saglani S, Bush A. Asthma in preschool children: the next challenge. Curr Opin Allergy Clin Immunol 2009;9:141-5.

25. Martinez FD, Wright AL, Taussig LM, Holberg CJ, Halonen M, Morgan WJ. Asthma and wheezing in the first six years of life. The Group Health Medical Associates. N Engl J Med 1995;332:133-8.

26. Taussig LM, Wright AL, Holberg CJ, Halonen M, Morgan WJ, Martinez FD. Tuscon Children's Respiratory Study: 1980 to present. J Allergy Clin Immunol 2003;111:661-75.

27. Kurukulaaratchy RJ, Fenn MH, Waterhouse LM, Matthews SM, Holgate ST, Arshad SH. Characterization of wheezing phenotypes in the first 10 years of life. Clin Exp Allergy 2003;33:573-8.

28. Trotter TL, Martin HM. Family history in pediatric primary care. Pediatrics 2007;120(Suppl 2):S60-5.

29. Yoos HL, Kitzman H, McMullen A, Sidora-Arcoleo $\mathrm{K}$, Anson E. The language of breathlessness: do families and health care providers speak the same language when describing asthma symptoms? J Pediatr Health Care 2005;19:197-205.

30. Tates K, Meeuwesen L. Doctor-patient-child communication: a (re)review of the literature. Soc Sci Med 2001;52:839-51.

31. Curtis-Tyler K. Levers and barriers to patient-centred care with children: findings from a synthesis of studies of the experiences of children living with type 1 diabetes or asthma. Child Care Health Dev 2011; 37:540-50.

32. Sutcliffe K, Alderson P, Curtis K. Children as partners in their diabetes care: an exploratory research study. London: Social Science Research Unit, Institute of Education, University of London; 2004.

33. Dell Clark C. In Sickness and in play: children cop- 
ing with chronic illness. Piscataway, NJ: Rutgers University Press; 2003.

34. Nabors L, Lehmkul H, Christos N, Andreone TL. Children with diabetes: perceptions of supports for self-management at school. J Sch Health 2003;73: 216-21.

35. Boyle JS, Baker RR, Kemp VH. 2004. School-based asthma: a study in an African American elementary school. J Transcult Nurs 2004;15:195-206.

36. Finnvold JE. Childhood asthma: regional and social inequalities in parents' perceptions of the diagnostic process in Norway. Nor Geogr Tidsskr 2009;63: $166-74$.

37. Cane RS, Ranganathan SC, McKenzie SA. What do parents of wheezy children understand by "wheeze"? Arch Dis Child 2000;82:327-32.

38. Cane RS, McKenzie SA. Parents' interpretations of children's respiratory symptoms on video. Arch Dis Child 2001;84:31-4.

39. Michel G, Silverman M, Strippoli M, et al. Parental understanding of wheezy and its impact on asthma prevalence estimates. Eur Respir J 2006;28:1124-30.

40. Saglani S, McKenzie SA, Bush A, Payne DN. A video questionnaire identifies upper airway abnormalities in pre-school children with reported wheeze. Arch Dis Child 2005;90:961-4.

41. Levy ML, Godfrey S, Irving CS, et al. Wheeze detection: recordings vs. assessment of physician and parent. J Asthma 2004;41:845-53.

42. Brodlie M, Graham C, McKean MC. Childhood cough. BMJ 2012;344:e1177.

43. Østergaard MS, Prahl P. Diagnosis of preschool asthma: parents' comments and typical phrases may ease history-taking. Prim Care Respir J 2007;16: 194-5.

44. Szefler SJ. Advances in pediatric asthma in 2010: addressing the major issues. J Allergy Clin Immunol 2011;127:102-15.

45. Dreger LC, Kozyrskyj AL, Hay Glass KT, Becker AB, MacNeil BJ. Lower cortisol levels in children with asthma exposed to recurrent maternal distress from birth. J Allergy Clin Immunol 2010;125:116-22.

46. Wright RJ, Visness CM, Calatroni A, et al. Prenatal maternal stress and cord blood innate and adaptive cytokines responses in an inner-city cohort. Am J Respir Crit Care Med 2010;182:25-33.

47. Brasholt M, Baty F, Bisgaard H. Physical activity in young children is reduced with increasing bronchial responsiveness. J Allergy Clin Immunol 2010;125: 1007-12.

48. Friedman T. Diagnosing asthma in young children: current research and recommendations. J Pediatr Health Care 2010;24:305-11.

49. Guilbert TW. Identifying and managing the infant and toddler at risk for asthma. J Allergy Clin Immunol 2010;126:417-22.
50. Townshend J, Hails S, Mckean M. Diagnosis of asthma in children. BMJ 2007;335:198-202.

51. Sly PD, Boner Al, Bjorksten B, et al. Early identification of atopy in the prediction of persistent asthma in children. Lancet 2008;372:1100-6.

52. Saglani S, Lenney W. Difficult asthma in the preschool child. Paediatr Respir Rev 2004;5:199-206.

53. Vance G, Lloyd K, Scadding G, et al. The 'unified airway': the RCPCH care pathway for children with asthma and/or rhinitis. Arch Dis Child 2011; 96(Suppl 2):i10-4.

54. Bacharier LB. Evaluation of the child with recurrent wheezing. J Allergy Clin Immunol 2011;128: 690.e1-5.

55. Bierman CW, Pearlman DS, editors. Allergic diseases from infancy to adulthood. 2nd ed. Philidelphia: WB Saunders Co; 1988.

56. Frey U, Stocks, J, Sly P, Bates J. Specification for signal processing and data handling used for infant pulmonary function testing. ERS/ATS Task Force on Standards for Infant Respiratory Function Testing. European Respiratory Society/American Thoracic Society. Eur Respir J 2000;16:1016-22.

57. Beydon N, Davis SD, Lombardi E, et al. An official American Thoracic Society/European Respiratory Society statement: pulmonary function testing in preschool children. Am J Respir Crit Care Med 2007;175:1304-45.

58. Crenesse D, Berlioz M, Bourrier T, Albertini $M$. Spirometry in children aged 3 to 5 years: reliability of forced expiratory maneuvers. Pediatr Pulmonol 2001;32:56-61.

59. Eigen H, Bieler M, Grant D, et al. Spirometric pulmonary function in healthy preschool children. Am J Respir Crit Care Med 2001;163(3 Pt 1):619-23.

60. Nystad W, Samuelsen SO, Nafstad P, Edvardsen E, Stensrud T, Jaakkola JJ. Feasibility of measuring lung function in preschool children. Thorax 2002; 57:1021-7.

61. Dallinga JW, Robroeks CM, van Berkel JJ, et al. Volatile organic compounds in exhaled breath as a diagnostic tool for asthma in children. Clin Exp Allergy 2010;40:68-78.

62. van de Kant KDG, Klaassen EMM, Jöbsis Q, Nijhuis AJ, van Schayck OCP, Dompeling E. Early diagnosis of asthma in young children by using noninvasive biomarkers of airway inflammation and early lung function measurements: study protocol of a case-control study. BMC Public Health 2009;9: 210.

63. Drews AC, Pizzichini MM, Pizzichini E, et al. Neutrophilic airway inflammation is a main feature of induced sputum in nonatopic asthmatic children. Allergy 2009;11:1597-601.

64. Devereux G, Litonjua AA, Turner SW, et al. Maternal vitamin $\mathrm{D}$ intake during pregnancy and early childhood wheezing. Am J Clin Nutr 2007; 85:853-9. 
65. Camargo CA Jr, Rifas-Shiman SL, Litonjua AA, et al. Maternal intake of vitamin D during pregnancy and risk of recurrent wheeze in children at $3 \mathrm{y}$ of age. Am J Clin Nutr 2007;85:788-95.

66. Azad MB, Konya T, Maughan H, et al. Gut microbiota of healthy Canadian infants: profiles by mode of delivery and infant diet at 4 months. CMAJ 2013; 185:385-94.

67. Lara M, Rosenbaum S, Rachelefsky G, et al. Improving childhood asthma outcomes in the United States: a blueprint for policy action. Pediatrics 2002;109: 919-30. 